\title{
ORIGINALARTICLE
}

\section{Effect of applying lactic acid bacteria and propionic acid on fermentation quality and aerobic stability of oats-common vetch mixed silage on the Tibetan plateau}

\author{
Jie ZHANG, ${ }^{1}$ Gang GUO, ${ }^{1}$ Lei CHEN, ${ }^{1}$ Junfeng LI, ${ }^{1}$ Xianjun YUAN, ${ }^{1}$ Chengqun $\mathrm{YU}^{2}{ }^{2}$ Masataka SHIMOJO${ }^{3}$ and \\ Tao SHAO ${ }^{1}$ \\ ${ }^{1}$ Institute of Ensiling and Processing of Grass, College of Animal Science and Technology, Nanjing Agricultural \\ University, Nanjing, ${ }^{2}$ Institute of Geographic Sciences and Natural Resources Research, Chinese Academy of \\ Sciences, Beijing, China and ${ }^{3}$ Department of Animal and Marine Bioresource Sciences, Faculty of Agriculture, \\ Kyushu University, Fukuoka, Japan
}

\begin{abstract}
The objective of this study was to evaluate effects of lactic acid bacteria and propionic acid on the fermentation quality and aerobic stability of oats-common vetch mixed silage by using a small-scale fermentation system on the Tibetan plateau. (i) An inoculant (Lactobacillus plantarum) (L) or (ii) propionic acid (P) or (iii) inoculant + propionic acid (PL) were used as additives. After fermenting for 60 days, silos were opened and the aerobic stability was tested for the following 15 days. The results showed that all silages were well preserved with low $\mathrm{pH}$ and $\mathrm{NH}_{3}-\mathrm{N}$, and high lactic acid content and $\mathrm{V}$-scores. $\mathrm{L}$ and $\mathrm{PL}$ silages showed higher $(P<0.05)$ lactic acid and crude protein content than the control silage. $\mathrm{P}$ silage inhibited lactic acid production. Under aerobic conditions, L silage had similar yeast counts as the control silage $\left(>10^{5} \mathrm{cfu} / \mathrm{g}\right.$ fresh matter (FM)); however, it numerically reduced aerobic stability for $6 \mathrm{~h}$. P and PL silages showed fewer yeasts $\left(<10^{5} \mathrm{cfu} / \mathrm{g}\right.$ FM) $(P<0.05)$ and markedly improved the aerobic stability $(>360 \mathrm{~h})$. The result suggested that PL is the best additive as it could not only improved fermentation quality, but also aerobic stability of oats-common vetch mixed silage on the Tibetan plateau.
\end{abstract}

Key words: aerobic stability, fermentation quality, lactic acid bacteria, oat-common vetch mixture, propionic acid.

\section{INTRODUCTION}

The Tibetan plateau occupies 2.5 million $\mathrm{km}^{2}$ (approximately $25 \%$ of the P.R. China). About $70 \%$ is highaltitude, cold, alpine rangeland (Cao et al. 2011), an average altitude of over $4000 \mathrm{~m}$ where it is regarded as the highest unique territorial unit in the world. Seldom crops are suitable for growing in the highland due to inherently extreme and unstable climate and natural environment, particularly facing frosts from November to early April. Therefore, forage production is limited and the shortage of feedstuffs has resulted in big seasonal body weight variations, low milk production and low fertility of animals. As a result, the development of animal husbandry is restricted in Tibet. Yak farmers have long been storing forage as hay for winter supplementary feed. However, dry matter (DM) and nutritive value losses often occur during the stage of hay making. In recent years, there has been growing interest in silage production in Tibet, mainly made from cereal-legume mixtures for production feeding purposes in beef, dairy and lamb enterprises. Ensiling could not only facilitate year-round fodder provision and avoid nutrition loss (Titterton $\delta$ Maasdorp 1997), but also decrease DM and nutritive value losses associated with hay making (Kaiser $\delta$ Curll 1987).

Oats (Avena sativa $\mathrm{L}$ ) and common vetch (Vicia sativa L) can be cultivated successfully on the Tibetan plateau due to hardy drought-tolerant characteristics. Farmers widely use the practice of intercropping to plant oats and common vetch in Tibet, as in other countries

Correspondence: Tao Shao, Institute of Ensiling and Processing of Grass, College of Animal Science and Technology, Nanjing Agricultural University, Nanjing 210095, China. (Email: taoshaolan@163.com)

Received 8 December 2013; accepted for publication 28 August 2014. 
(Assefa \& Ledin 2001; Lauriault \& Kirksey 2004). In this way, year-to-year variation in the nutritive value of whole-crop cereal silage due to changing ear-tostraw ratio is likely to be less. Moreover, there is a reduced need to apply $\mathrm{N}$ fertilizer through the use of $\mathrm{N}$-fixating legumes. The legumes component is sought to improve yield and crude protein (CP) content of the final forage (Lunnan 1989). Furthermore, silage of high quality can be made by ensiling mixtures of legumes and cereal crops (Kennelly \& Weinberg 2003). Such silages are also suggested to improve rumen microbial yields and supply balanced protein and energy for rumen microbe growth (Adesogan \& Salawu 2004).

Lactic acid bacteria (LAB) containing homofermentative bacteria have become popular silage additives as they are non-corrosive and easy to use. Natural epiphytic LABs are usually found in low numbers in fresh crops (Weinberg et al. 1993). Homofermentative bacteria reduce nutrient losses in ensiled forages by increasing the rate of lactate production and acidification. However, use of such inoculants can predispose silages to aerobic deterioration because they result in relatively greater levels of residual water-soluble carbohydrates (WSC) and lactate, which are used as growth substrates by spoilage-causing yeasts and molds (Huisden et al. 2009).

In Tibet, agricultural areas are far from pastoral areas, long distance transportation is essential, and yak farmers do not know how to feed silages scientifically. During long-distance transport and stages between opening silos and feeding, silages are often exposed to air for a long time, thus it is susceptible to aerobic deterioration. Propionic acid has the greatest antimycotic activity among the short-chain fatty acids (Woolford 1975); it has been used as a forage preservative for many years when used at high rates (1.0$3.0 \%$ ) on a DM basis and is deemed to be an effective inhibitor of aerobic deterioration of silage (Woolford 1984). The antimycotic effect of propionic acid is enhanced as pH declines (Woolford 1975), making it an ideal candidate to improve the aerobic stability of silage when $\mathrm{pH}$ is low. Few studies have investigated the effect of additives on ensiling characteristics and aerobic stability of oat-common vetch mixed silage on the Tibetan plateau.

The objective of the present experiment was to study the effect of LAB and propionic acid on the fermentation quality and aerobic stability of oatscommon vetch mixed silage on the Tibetan plateau.

\section{MATERIAL AND METHODS Silage preparation}

Oats and common vetch were intercropped with ratio based on sowing rate $(137 \mathrm{~kg} / \mathrm{ha})$ on 18 May 2012 in the experimental field of the Grassland Station of Rikaze $\left(29.27^{\circ} \mathrm{N}\right.$, $88.88^{\circ} \mathrm{E}$, Tibet, China); the ratio is regular in Tibet. The $\mathrm{pH}$ of the soil was 8.1 , total $\mathrm{N}$ content of $5.4 \mathrm{~g} / \mathrm{kg}$, total potassium content of $13.0 \mathrm{~g} / \mathrm{kg}$, total P content of $0.7 \mathrm{~g} / \mathrm{kg}$. Oats were harvested at the milk stage ( $318 \mathrm{~g} \mathrm{DM} / \mathrm{kg}$ fresh weight) and common vetch harvested at podding stage (296 g DM/kg fresh weight). Crops were cut at approximately $5 \mathrm{~cm}$ above the ground by hand using a sickle. Legume plants were separated from oats plants and sampled as whole plants for microbiological analyses. Forage was chopped with a conventional forage harvester to a length of $2-3 \mathrm{~cm}$ and sampled to determine the DM content and chemical composition. The heights of herbage of oats and common vetch in the stand at harvest were 83 and $57 \mathrm{~cm}$ respectively, and the proportion of oats and common vetch in the intercrops on a fresh matter (FM) basis was 3:7. Mixed forage (309 g DM/kg fresh weight) was ensiled with four different treatments: no additive (control); lactic acid bacteria (Lactobacillus plantarum) addition at $10^{6}$ colony-forming units $(\mathrm{cfu}) / \mathrm{g}(\mathrm{L})$; propionic acid addition at $0.4 \%(\mathrm{P})$; and $10^{6} \mathrm{cfu} / \mathrm{g} \mathrm{LAB}+0.4 \%$ propionic acid addition (PL) on a FM basis of mixed forage. Additives were diluted with deionized water and applied with a hand-held sprayer, and then forage samples were stirred manually. A similar quantity of deionized water was sprayed on the control forage. From each treatment of forage mixture, samples of $760 \mathrm{~g}$ were packed into a laboratory silo (polyethylene bottle, 1 L capacity), followed by being sealed with a screw top and plastic tapes, and then kept at ambient temperature. The silos for each treatment were opened on day 60 after ensiling, and then subjected to an aerobic stability test for 15 days. Triplicate silos were made for each treatment on each sampling day.

\section{Chemical and microbiological analyses}

Fresh forage and unfermented mixed forage were analyzed for chemical and microbiological composition. To measure fermentation indices, $35 \mathrm{~g}$ of each mixed silage was blended with $75 \mathrm{~mL}$ of deionized water extracted at $4^{\circ} \mathrm{C}$ for $24 \mathrm{~h}$. Then, the extracts were filtered through two layers of cheesecloth and a filter paper (Xinhua Co, Hangzhou, China). The filtrates were used for determining $\mathrm{pH}$, buffering capacity (BC), ammonia- $\mathrm{N}\left(\mathrm{NH}_{3}-\mathrm{N}\right)$, lactic acid (LA) and volatile fatty acids (VFAs) contents. The $\mathrm{pH}$ of the silage was measured with a glass electrode $\mathrm{pH}$ meter (HANNA pH 211 , Hanna Instruments Italia Srl, Villafranca Padovana, Italy). Buffering capacity was determined by the hydrochloric acidsodium hydroxide method of Playne and McDonald (1966). The DM content of unensiled forage samples and silage samples were determined by drying the samples at $65^{\circ} \mathrm{C}$ for $48 \mathrm{~h}$ to a constant mass, and then ground to pass through a $2 \mathrm{~mm}$ screen for later analysis. Crude ash (Ash) was determined by placing samples in a muffle furnace set at $500^{\circ} \mathrm{C}$ for $5 \mathrm{~h}$. The WSC were determined by colorimetric analysis after reaction with anthrone reagent (Thomas 1977). The fermentation coefficient (FC) of each forage was predicted according to the formula: $\mathrm{FC}=\mathrm{DM} \%+8 \mathrm{WSC} / \mathrm{BC}$ (Weissbach $\&$ Honig 1996). $\mathrm{NH}_{3}-\mathrm{N}$ was determined using the phenol-hypochlorite reaction method of Broderick and Kang (1980). The methods of Van Soest et al. (1991) were used for neutral detergent fiber (NDF) and acid detergent fiber (ADF) analysis and the analyses were not sequential. Amylase and sodium sulfite were used in the NDF analysis and the results were expressed on a DM basis inclusive of ash. Total nitrogen (TN) was analyzed by the Kjeldahl procedure (Krishnamoorthy et al. 1982), CP was determined as the TN multiplied by 6.25 . Ether extract (EE) was determined according to Horii et al. 
(1971). The LA was determined by the method of Barker and Summerson (1941). VFAs were determined with gas chromatography (Shimadzu GC-17A, Shimadzu, Kyoto, Japan, with $30 \mathrm{~m} \times 0.25 \mathrm{~mm}$ (df $0.25 \mu \mathrm{m}$ ) capillary column, acidmodified poly (ethylene glycol) phase, GADA-24107, SigmaAldrich Co., Tokyo, Japan; condition: column temperature $130^{\circ} \mathrm{C}$, injection temperature $220^{\circ} \mathrm{C}$ ). To assess the quality of the silage, we calculated the V-score from the $\mathrm{NH}_{3}-\mathrm{N} / \mathrm{TN}$ and VFA concentrations (Takahashi et al. 2005).

The mixed samples $(10 \mathrm{~g})$ were blended with $90 \mathrm{~mL}$ of sterilized water, and serially diluted in sterilized water. Enumeration of yeasts and $\mathrm{LAB}$ was done from the fresh forage and silages (day 60). The number of LAB were measured by plate count on Lactobacilli de Man, Rogosa, Sharpe (MRS) agar incubated at $30^{\circ} \mathrm{C}$ for $48 \mathrm{~h}$ under anaerobic conditions (Anaerobic box; YIHENG Technical co., Ltd, Shanghai, China). Yeasts were counted on potato dextrose agar (Sincere Biotech co., Ltd, Shanghai, China) and incubated for $48 \mathrm{~h}$ at $30^{\circ} \mathrm{C}$. Colonies were counted as viable numbers of microorganisms (cfu/g of FM) from plates containing a minimum of 30 and a maximum of 300 colonies. All the microbiological data were log transformed.

\section{Aerobic stability test}

After a silo was once thoroughly emptied, half (by weight) of the content was put into a polythene bottle $(0.5 \mathrm{~L}$ capacity) without compaction. The top was left uncovered and a conventional alcohol thermometer was placed in the centre of the silage. The bottles were kept in a room maintained at $25^{\circ} \mathrm{C}$, and the temperature was monitored every $12 \mathrm{~h}$. Spoilage was considered to have occurred if the difference between silage and surrounding air reached $2^{\circ} \mathrm{C}$ (Weinberg 2008). A total of 48 silos were opened at 60 days and then subjected to aerobic deterioration test for 15 days. Triplicate silages of each treatment were removed at $0,5,10$ and 15 days after aerobic exposure, and the silages were sampled to determine $\mathrm{pH}$ values, LA, VFAS and WSC levels as well as yeast counts. These wet samples were stored at $-20^{\circ} \mathrm{C}$, except for the samples used to determine the microorganisms, which were evaluated immediately.

\section{Statistical analyses}

Analyses were performed using the general linear model procedure of SAS (SAS Institute Inc., Cary, NC, USA). Data on chemical and microbiological composition of fresh and ensiled mixture of oats and common vetch were subjected to one-way analysis of variance (ANOVA). In aerobic conditions, experiments were carried out according to a randomized factorial design, the data were subjected to twoway ANOVA with treated silages and deterioration period as two factors. Differences among means were tested using Tukey's test. Differences were considered significant when probability was less than 0.05 .

\section{RESULTS \\ Chemical composition of materials}

The chemical composition and microbial counts of oats, common vetch and their mixture before ensiling are presented in Table 1. The DM content of the mixture was $309 \mathrm{~g} / \mathrm{kg}$ fresh weight. The WSC content was $164 \mathrm{~g} / \mathrm{kg}$ DM. The BC and CP contents of the mixture were $306 \mathrm{mEq} / \mathrm{kg}$ DM and 13.5\% DM respectively. The numbers of epiphytic LAB on the mixture were more than $1.0 \times 10^{5} \mathrm{cfu} / \mathrm{g}$ FM and yeasts were $1.0 \times 10^{4} \mathrm{cfu} / \mathrm{g}$ FM.

\section{Fermentation quality of mixture silage after 60 days of ensiling}

The fermentation quality and the microbial composition of mixed silages after 60 days of ensiling are presented in Table 2. All mixed silages showed low pH value, which was below 4.0, and PL silage had the lowest $\mathrm{pH}$. L silage had the highest LA content followed by PL silage and then the control and P silages. In contrast, treatment with additives resulted in a marked decrease $(P<0.05)$ in the contents of acetic acid, and PL silage had the lowest acetic acid content. Lactic acid/acetic acid ratio was significantly higher $(P<0.05)$ in $\mathrm{L}$ and PL silages than that in the control silage, and PL silage had the highest LA /acetic acid content. P and PL silages showed higher $(P<0.05)$ propionic acid contents as compared with the control

Table 1 Chemical and microbial composition of herbage before being ensiled

\begin{tabular}{|c|c|c|c|}
\hline Items & Oat & Common vetch & Mixture $†$ \\
\hline $\mathrm{DM}(\%)$ & 31.7 & 28.6 & 30.9 \\
\hline $\mathrm{pH}$ & 6.17 & 5.68 & 5.79 \\
\hline WSC (g/kg DM) & 183 & 113 & 164 \\
\hline Buffering capacity (mEq/kg DM) & 245 & 463 & 306 \\
\hline Fermentation coefficient $\ddagger$ & 37.7 & 30.6 & 35.2 \\
\hline Crude protein (\% DM) & 11.3 & 19.4 & 13.5 \\
\hline Ether extract (\% DM) & 4.96 & 4.44 & 4.85 \\
\hline Ash (\% DM) & 6.55 & 7.00 & 6.69 \\
\hline Neutral detergent fiber (\% DM) & 48.9 & 40.9 & 46.7 \\
\hline Acid detergent fiber (\% DM) & 25.1 & 21.0 & 24.0 \\
\hline Lactic acid bacteria $\left(\log _{10} \mathrm{cfu} / \mathrm{g} \mathrm{FM}\right)$ & 6.38 & 3.05 & 5.41 \\
\hline Yeast $\left(\log _{10} \mathrm{cfu} / \mathrm{g} \mathrm{FM}\right)$ & 4.94 & 3.76 & 4.60 \\
\hline
\end{tabular}

†Mixture: $70 \%$ oat and $30 \%$ common vetch on a fresh matter basis of mixture. $\ddagger$ Fermentation coefficient $=\mathrm{DM} \%+8 \mathrm{WSC} / \mathrm{BC}$. DM, dry matter; FM, fresh matter; WSC, water soluble carbohydrate. 
Table 2 Fermentation characteristics and microbial composition of four mixed silages after 60 days of ensiling

\begin{tabular}{|c|c|c|c|c|c|}
\hline \multirow[t]{2}{*}{ Item } & \multicolumn{4}{|c|}{ Treatments } & \multirow[t]{2}{*}{ SEM } \\
\hline & Control & $\mathrm{L}$ & $\mathrm{P}$ & PL & \\
\hline $\mathrm{pH}$ & $3.98 \mathrm{a}$ & $3.83 \mathrm{~b}$ & $3.86 \mathrm{ab}$ & $3.78 \mathrm{c}$ & 0.02 \\
\hline Lactic acid (g/kg DM) & $71.9 \mathrm{~b}$ & $100.7 a$ & $49.4 \mathrm{c}$ & $98.6 a$ & 6.41 \\
\hline Acetic acid (g/kg DM) & $18.7 \mathrm{a}$ & $11.6 \mathrm{c}$ & $15.1 \mathrm{~b}$ & $9.6 \mathrm{~d}$ & 1.06 \\
\hline Lactic acid /acetic acid & $3.85 c$ & $8.69 b$ & $3.27 c$ & $10.28 \mathrm{a}$ & 0.92 \\
\hline Propionic acid (g/kg DM) & $5.18 \mathrm{c}$ & $0.65 \mathrm{~d}$ & $12.81 \mathrm{~b}$ & $16.29 \mathrm{a}$ & 1.86 \\
\hline Butyric acid (g/kg DM) & $1.50 \mathrm{a}$ & $0.81 \mathrm{~b}$ & $0.61 b$ & $0.81 \mathrm{~b}$ & 0.10 \\
\hline VFAS (g/kg DM) & $25.4 \mathrm{~b}$ & $13.1 \mathrm{c}$ & $28.5 \mathrm{a}$ & $26.7 b$ & 1.84 \\
\hline WSC (g/kg DM) & $40.3 \mathrm{bc}$ & $35.9 c$ & $52.2 \mathrm{a}$ & $48.0 \mathrm{ab}$ & 2.16 \\
\hline $\mathrm{NH}_{3}-\mathrm{N}(\mathrm{g} / \mathrm{kg} \mathrm{TN})$ & $81.0 \mathrm{a}$ & $70.9 \mathrm{~b}$ & $58.7 \mathrm{c}$ & $49.5 d$ & 3.64 \\
\hline Lactic acid bacteria $\left(\log _{10} \mathrm{cfu} / \mathrm{g} F M\right)$ & $6.30 \mathrm{~b}$ & $7.74 \mathrm{a}$ & $5.71 \mathrm{c}$ & $6.72 b$ & 0.14 \\
\hline Yeasts $\left(\log _{10} \mathrm{cfu} / \mathrm{g} F \mathrm{FM}\right)$ & $<2.00$ & $<2.00$ & $<2.00$ & $<2.00$ & 0.00 \\
\hline V-score & 86 & 94 & 91 & 93 & 1.03 \\
\hline
\end{tabular}

Values in the same row (a-d) with different following letters are significantly different $(P<0.05)$. DM, dry matter; L, lactic acid bacteria (Lactobacillus plantarum); P, propionic acid; PL = lactic acid bacteria + propionic acid; SEM, standard error of the mean; TN, total nitrogen; WSC, water soluble carbohydrate; VFAS, volatile fatty acids.

Table 3 Chemical composition of four mixed silages after 60 days of ensiling

\begin{tabular}{|c|c|c|c|c|c|}
\hline \multirow[t]{2}{*}{ Item } & \multicolumn{4}{|c|}{ Treatments } & \multirow[t]{2}{*}{ SEM } \\
\hline & Control & $\mathrm{L}$ & $\mathrm{P}$ & PL & \\
\hline DM (\%) & $30.16 a$ & $28.18 b$ & $30.44 a$ & $28.94 \mathrm{ab}$ & 0.33 \\
\hline Crude protein (\% DM) & $13.75 b$ & $14.86 a$ & $14.54 \mathrm{a}$ & $14.99 a$ & 0.15 \\
\hline Ether extract (\% DM) & $5.71 b$ & $6.45 \mathrm{a}$ & $5.67 \mathrm{~b}$ & $6.50 \mathrm{a}$ & 0.14 \\
\hline Neutral detergent fiber (\% DM) & $45.20 \mathrm{a}$ & $43.50 \mathrm{~b}$ & $45.52 a$ & $43.29 b$ & 3.06 \\
\hline Acid detergent fiber (\% DM) & $22.22 \mathrm{a}$ & $21.85 a$ & $21.66 a$ & $20.14 b$ & 2.49 \\
\hline Ash (\% DM) & $7.17 \mathrm{a}$ & $7.37 \mathrm{a}$ & $7.14 \mathrm{a}$ & $7.73 a$ & 0.04 \\
\hline
\end{tabular}

DM, dry matter; L, lactic acid bacteria (Lactobacillus plantarum); P, propionic acid; PL = lactic acid bacteria + propionic acid; SEM, standard error of the mean. Values in the same row $(\mathrm{a}-\mathrm{d})$ with different following letters are significantly different $(P<0.05)$.

silage, while only small amounts of propionic acid were found in the L silage. The contents of butyric acid in the treated silages were significantly lower than that in the control silage $(P<0.05)$. The residual WSC content in $\mathrm{P}$ silage was significantly higher $(P<0.05)$ than that in the control silage, the residual WSC content in PL silage numerically higher than that in the control silage, and L had the lowest residual WSC content. The $\mathrm{NH}_{3}-\mathrm{N} / \mathrm{TN}$ ratio of treated silages were lower $(P<0.05)$ than that of the control silage, and lowest $\mathrm{NH}_{3}-\mathrm{N} / \mathrm{TN}$ ratio was found in PL silage $(49.53 \mathrm{~g} / \mathrm{kg} \mathrm{DM})$. The counts of LAB in L silage were as high as $10^{7} \mathrm{cfu} / \mathrm{g}$, which was higher $(P<0.05)$ than that in the control silage, while the counts of LAB in $\mathrm{P}$ silage were lower $(P<0.05)$ than that in the control silage. Yeasts populations in all mixed silages were reduced to below the detectable level $\left(<10^{2} \mathrm{cfu} / \mathrm{g} \mathrm{FM}\right)$.

Chemical composition of four mixed silages after 60 days of ensiling is presented in Table 3. In addition, DM of L silage was lower $(P<0.05)$ than the control and P silages, while EE of L and PL silages were higher $(P<0.05)$ than that of the control or $P$ silages. Silages treated with $\mathrm{L}$ and PL had lower $(P<0.05)$ contents of NDF as compared with the control and P silages, and silages treated with PL had lower $(P<0.05)$ content of $\mathrm{ADF}$ than that of other silages. No notable differences
Table 4 Effect of additives on the aerobic stability $\left(2^{\circ} \mathrm{C}\right.$ above the ambient temperature) of four mixed silages after exposure to air

\begin{tabular}{llllll}
\hline Item & \multicolumn{4}{c}{ Treatment } & SEM \\
\cline { 2 - 5 } & Control & L & P & PL \\
\hline
\end{tabular}

Aerobic stability (h) $212 b \quad 206 b \quad>360 a \quad>360 a \quad 22.73$

Values in the same row $(\mathrm{a}-\mathrm{d})$ with different following letters are significantly different $(P<0.05)$. L, lactic acid bacteria (Lactobacillus plantarum); $\mathrm{P}$, propionic acid; $\mathrm{PL}=$ lactic acid bacteria + propionic acid; SEM, standard error of the mean.

occurred in Ash, while CP increased $(P<0.05)$ with addition of additives.

\section{Effects of LAB and propionic acid application on aerobic stability}

The aerobic stability of the mixture silages is presented in Table 4. The duration of aerobic stability of the silages ranged from 206 to $>360 \mathrm{~h}$. The silage treated with $\mathrm{L}$ was the first to spoil, numerically reduced at $6 \mathrm{~h}$ as compared with the control silage. Treatment with $\mathrm{P}$ and PL markedly improved $(P<0.05)$ the aerobic stability of the silages. Both of them did not deteriorated by the end of the 15 days temperature-monitoring period. 
Table 5 Chemical and microbial composition of four mixed silages after exposure to air

\begin{tabular}{|c|c|c|c|c|c|c|c|c|c|c|}
\hline \multirow[t]{2}{*}{ Item } & \multirow[t]{2}{*}{ Treatments } & \multicolumn{4}{|c|}{ Days after unloading } & \multirow[t]{2}{*}{ Mean } & \multicolumn{3}{|c|}{ Analysis of variance } & \multirow[t]{2}{*}{ SEM } \\
\hline & & 0 & 5 & 10 & 15 & & $\mathrm{~T}$ & $\mathrm{D}$ & $\mathrm{T} \times \mathrm{D}$ & \\
\hline \multirow[t]{4}{*}{$\mathrm{pH}$} & Control & $3.99 \mathrm{c}$ & $3.86 \mathrm{c}$ & $4.60 \mathrm{~b}$ & $5.43 a$ & $4.47 \mathrm{a}$ & $* *$ & ** & $* *$ & 0.19 \\
\hline & $\mathrm{L}$ & $3.83 c$ & $3.72 \mathrm{c}$ & $4.39 \mathrm{~b}$ & $5.20 \mathrm{a}$ & $4.29 \mathrm{~B}$ & & & & 0.18 \\
\hline & $\mathrm{P}$ & $3.86 a$ & $3.78 \mathrm{a}$ & $3.77 a$ & $3.76 a$ & $3.79 \mathrm{D}$ & & & & 0.02 \\
\hline & PL & $3.78 \mathrm{~b}$ & $3.81 \mathrm{~b}$ & $3.91 \mathrm{~b}$ & $4.25 a$ & $3.94 \mathrm{C}$ & & & & 0.06 \\
\hline \multirow[t]{4}{*}{ Lactic acid (g/kg DM) } & Control & $71.86 a$ & $70.90 \mathrm{ab}$ & $63.52 \mathrm{ab}$ & $39.44 b$ & $61.43 \mathrm{~B}$ & ** & $* *$ & $* *$ & 4.15 \\
\hline & $\mathrm{L}$ & $100.69 a$ & $98.72 \mathrm{a}$ & $73.86 a b$ & $51.40 \mathrm{~b}$ & $81.17 \mathrm{~A}$ & & & & 6.20 \\
\hline & $\mathrm{P}$ & $49.35 a$ & $54.31 \mathrm{a}$ & $60.48 a$ & $52.60 a$ & $54.18 \mathrm{~B}$ & & & & 1.39 \\
\hline & PL & $98.64 a$ & $90.69 a$ & $93.14 a$ & $69.02 b$ & 87.87A & & & & 5.95 \\
\hline \multirow{4}{*}{ WSC (g/kg DM) } & Control & $40.29 a$ & $35.08 \mathrm{a}$ & $25.69 b$ & $26.05 b$ & $31.78 \mathrm{~B}$ & ** & $* *$ & $* *$ & 1.96 \\
\hline & $\mathrm{L}$ & $35.91 \mathrm{a}$ & $32.81 \mathrm{a}$ & $30.51 \mathrm{a}$ & $22.89 c$ & $30.53 \mathrm{~B}$ & & & & 1.53 \\
\hline & $\mathrm{P}$ & $52.21 \mathrm{a}$ & $45.71 a$ & $38.54 \mathrm{~b}$ & $34.55 b$ & $42.75 \mathrm{~A}$ & & & & 2.05 \\
\hline & PL & $47.97 a$ & $44.75 a b$ & $40.96 b$ & $29.12 \mathrm{c}$ & $40.70 \mathrm{~A}$ & & & & 2.30 \\
\hline \multirow[t]{4}{*}{ VFAs (g/kg DM) } & Control & $25.40 \mathrm{a}$ & $28.75 a$ & $18.74 b$ & $9.15 c$ & $20.51 \mathrm{C}$ & ** & $* *$ & $* *$ & 2.26 \\
\hline & $\mathrm{L}$ & $13.06 \mathrm{~b}$ & $21.15 a$ & $16.12 \mathrm{ab}$ & $11.00 \mathrm{~b}$ & $15.33 \mathrm{D}$ & & & & 1.22 \\
\hline & $\mathrm{P}$ & $28.49 \mathrm{bc}$ & $38.00 a$ & $30.35 b$ & $23.37 c$ & $30.05 \mathrm{~A}$ & & & & 1.79 \\
\hline & PL & $26.71 \mathrm{a}$ & $26.74 a$ & $24.95 a$ & $23.40 a$ & $25.45 B$ & & & & 0.73 \\
\hline \multirow[t]{4}{*}{ Yeasts $\left(\log _{10} \mathrm{cfu} / \mathrm{g} \mathrm{FM}\right)$} & Control & $2.00 \mathrm{~b}$ & $8.46 a$ & $8.75 a$ & $8.58 \mathrm{a}$ & $6.95 \mathrm{~A}$ & $* *$ & $* *$ & $* *$ & 0.86 \\
\hline & $\mathrm{L}$ & $2.00 \mathrm{c}$ & $7.12 \mathrm{c}$ & $8.09 \mathrm{~b}$ & $8.50 a$ & $6.42 \mathrm{C}$ & & & & 0.49 \\
\hline & $\mathrm{P}$ & $2.00 \mathrm{c}$ & $3.53 b$ & $4.27 a$ & $4.60 a$ & $3.60 \mathrm{D}$ & & & & 0.31 \\
\hline & PL & $2.00 \mathrm{c}$ & $4.60 \mathrm{~b}$ & $4.60 \mathrm{~b}$ & $4.74 a$ & $3.98 \mathrm{~B}$ & & & & 0.64 \\
\hline
\end{tabular}

$* * P<0.01$. Values in the same row (a-d) or in the same column $(\mathrm{A}-\mathrm{D})$ with different following letters are significantly different $(P<0.05)$. D, effect of deterioration period; DM, dry matter; L, lactic acid bacteria (Lactobacillus plantarum); P, propionic acid; PL $=$ lactic acid bacteria + propionic acid; SEM, standard error of the mean; T, effect of treatment; VFAs, volatile fatty acids; WSC, water soluble carbohydrate.

Chemical and microbial compositions of four mixed silages after exposure to air are presented in Table 5. Yeast numbers were $>1 \times 10^{7} \mathrm{cfu} / \mathrm{g}$ in the control and $\mathrm{L}$ silages, while yeast numbers were still $<1 \times 10^{5} \mathrm{cfu} / \mathrm{g}$ in $\mathrm{P}$ and PL silages after aerobic exposure for 15 days. The LA content began to decrease at the beginning of the deterioration test in control silage and reached the lowest value at 15 days, quickly raising the $\mathrm{pH}$ from 3.99 to 5.43. Similar with the control silage, the LA content decreased gradually in L silage and reached the lowest value in the treated silages at the end of the aerobic stability test; the $\mathrm{pH}$ rose from 3.83 to 5.20 . The LA content decreased significantly $(P<0.05)$ in PL silage at 15 days, and the $\mathrm{pH}$ increased significantly $(P<0.05)$ at 15 days. The LA content peaked until 10 days and then decreased in $\mathrm{P}$ silage. The $\mathrm{pH}$ was thus maintained as low as 4.25 until aerobic exposure was terminated after 15 days. The VFAS content decreased gradually in the control silage, the VFAS content in L silage increased significantly $(P<0.05)$ during the first 5 days of aerobic exposure, and then decreased, while the VFAS contents in P and PL silages did not change significantly. The WSC contents decreased gradually in all silages with time of aerobic exposure. After aerobic exposure, the L silage had the lowest WSC content and $P$ silage had the highest WSC content.

\section{DISCUSSION}

\section{Chemical composition of materials}

The DM content of a crop influences strongly the rate and extent of the fermentation result; a clostridial fer- mentation and subsequent poor acceptance of the silage by the animals might result from a low DM content with low sugar content at ensiling (Fraser et al. 2000). For proper ensiling, a material must have high content of WSC and adequate LAB prior to ensiling (Weinberg 2008). Well-fermented silages are produced from forages in which FCs are greater than 35 , but are dependent on the nature of the epiphytic LAB number; a minimum number of $\mathrm{LAB}$ to suppress clostridial activity is suggested to be $1 \times 10^{5} \mathrm{cfu} / \mathrm{g}$ FM of herbage (Weissbach \& Honig 1996). In the present study, the WSC, CP and organic matter contents of oats and common vetch were higher than that reported in the literature for oats and common vetch (Shao et al. 2005; Pursiainen \& Tuori 2008), which might have resulted from the large diurnal differences in temperature and long hours of sunshine on the Tibetan plateau. Temperature and sunshine affect plant nutrient accumulation; high temperatures and long hours of sunshine favor photosynthesis to produce organic matter; low temperature at night can suppress forage respiration to decrease the content of organic matter degradation. Four mixture forage before ensiling contained high WSC content, proper DM content, FC was 35 and LAB numbers were more than $1 \times 10^{5} \mathrm{cfu} / \mathrm{g} \mathrm{FM}$, which is critical for a successful fermentation.

\section{Effects of $L A B$ and propionic acid application on fermentation quality}

After ensiling for 60 days, the $\mathrm{pH}$ of the four mixture silages reduced to 4.2 or less, which was 
characteristic of well-preserved silages (Weinberg 2008). Ammonia-N production is related to CP degradation in all silages, which reveals the extent of proteolysis in silage (Wilkinson 2005) and wellpreserved silages should have less than $100 \mathrm{~g} \mathrm{NH}_{3}-$ $\mathrm{N} / \mathrm{kg}$ TN (McDonald et al. 2002). In the present study all silages had values less than $81 \mathrm{~g} \mathrm{NH}_{3}-\mathrm{N} / \mathrm{kg} \mathrm{TN}$, indicating that extensive protein proteolysis is unlikely to have occurred. Compared to the untreated silage, the LAB additive significantly increased the LA contents in the L and PL silages, which might be attributed to higher WSC content that could provide more substrates for LAB fermentation, thus allowing a rapid production of lactic acid by L. plantarum, and suppresses the buffering effect of legumes as suggested by Adesogan and Salawu (2002). Lower contents of acetic acid and higher LA/acetic acid ratio in L and PL silages as compared with untreated silage indicated a more homofermentative process. Muck and Kung (1997) concluded that microbial inoculation lowered the $\mathrm{pH}$ and improved the LA/acetic acid ratio in more than $60 \%$ of studies conducted between the years 1990 to 1995. In contrast, lower LA content in P silage might be attributed to inhibition of LAB activity by propionic acid. Britt et al. (1977) reported that LA contents of silages were decreased $(P<0.01)$ by addition of propionic acid, which suggests an inhibition of microbial activity. $\mathrm{P}$ silage also showed significantly $(P<0.05)$ lower acetic acid content as compared with the control silage. This might be explained as propionic acid application suppressed acetic acid producing bacteria activity during fermentation (Woolford 1975). The WSC are the main source of food for microorganisms during silage fermentation. Propionic acid is a potentiality antimycotic agent; during the early stage of ensiling, propionic acid could effectively inhibit the undesirable microorganisms activity, resulting in minimizing the consumption of WSC by undesirable microorganisms (Woolford 1975; Moon 1983). A higher butyric acid content was found in the control silage, which might be attributed to clostridial fermentation in the early stage of ensiling; this corresponds with higher $\mathrm{NH}_{3}-\mathrm{N}$ content in the control silage.

Crude ash content increased a little throughout the experiment, which might be attributed to DM loss. Garcia et al. (1989) reported that the increase in ash content as percentage of DM is indicated by DM loss. Consistent with the findings of Bilal (2009), the CP of the treated mixed silages also increased, which might be attributed to efficient fermentation, preservation and stability of silage, reducing protein breakdown by plant enzymes and the growth of proteolytic microorganisms, the increase in CP content as percentage of DM might be also indicated by DM loss. The NDF contents of the L and PL silages were much lower than that of the control and $\mathrm{P}$ silages, which might have been a result of increased microbial respiration and fermentation of the fiber fraction. This result is consistent with that of Mandebvu et al. (1999). Silage treated with PL had lower $(P<0.05)$ content of ADF than that of other silages and could be attributed to a combination of increased fermentation and acid hydrolysis of the fiber fraction which was consistent with results of Baytok et al. (2005). The numbers of yeasts in the final silages were very low, which is below the detectable level indicating strictly anaerobic conditions during ensiling. Similar findings have been reported by Pursiainen and Tuori (2008). The result showed that L and PL silages had better fermentation quality as indicated by higher LA and CP content, lower $\mathrm{pH}$ and acetic acid content than other silages.

\section{Effects of $L A B$ and propionic acid application on aerobic stability}

When fermentation is completed and silage is exposed to air during feedout or storage (leaky silos, holes in bag silos, poorly packed silage), heating in the silo and feed bunk is usually initiated by yeasts. (Ranjit $\&$ Kung 2000). Changes occur in chemical and microbial composition, when the aerobically stable and yeastcontaminated silage is exposed to air. As the climate is inherently unstable and there are large differences in day and night temperatures on the Tibetan plateau, it is difficult to control the temperature change of silage in the open air. Measuring the temperature change of silages in the open air could not properly reflect their aerobic stability. In addition, there is no information on evaluating aerobic stability of oat-common vetch mixed silage by measuring the temperature change on the Tibetan plateau. Therefore, our assessment of the aerobic stability of oats-common vetch mixed silage was based on changes in sample temperature under laboratory conditions as well as changes in chemical composition and microbial populations with time of aerobic exposure in the open air.

According to the evidence that silages of greater levels of LA or those with more residual sugar contents were less stable when exposed to air (Huisden et al. 2009), it was anticipated that the control and L silages would deteriorate rapidly. The same result was observed in the control and L silages. The $\mathrm{pH}$ of the control and L silages increased gradually with the time of aerobic exposure which might be attributed to the decreasing of LA content. The $\mathrm{pH}$ was an indicator of aerobic deterioration of the silage because LA was consumed by yeasts during aerobic exposure, and then the silage becomes suitable for the growth of other undesirable microorganisms such as mold and aerobic bacteria (Basso et al. 2012). However, the opposite result was observed in $\mathrm{P}$-treated mixed silage. The $\mathrm{pH}$ value of $P$ silage did not change throughout the whole stage of aerobic exposure, which might be attributed to the increase of LA content. During the 15 days of exposure to air, LA content in $\mathrm{P}$ silage gradually 
increased until 10 days and then decreased. This increase might be attributed to the volatilization and/or metabolism of propionic acid which resulted in lactate producers using the residual readily available carbohydrate during the normal fermentation periods. Yeasts have long been thought to be responsible for the aerobic deterioration of silage and silage containing more than $1 \times 10^{5} \mathrm{cfu}$ of yeasts $/ \mathrm{g}$ is prone to undergo aerobic deterioration once exposed to air (Mcdonald et al. 1991). Our results confirmed lower yeast numbers in $\mathrm{P}$ and PL silages as compared with the control and L silages on aerobic exposure for 5, 10 and 15 days. Yeast populations in P and PL silages were maintained below $10^{5} \mathrm{cfu} / \mathrm{g}$ FM during the aerobic exposure. This may be due to propionic acid which is an antimicrobial agent, and high content of propionic acid could inhibit yeast growth, which is consistent with the findings of Huber and Soejono (1977). Thus, $\mathrm{P}$ and PL silage showed the greatest aerobic stability $(>360 \mathrm{~h})$ of all the silages. L silage numerically reduced aerobic stability for $6 \mathrm{~h}$ as compared with the control silage which might be attributed to the lower content of VFAs as compared with the control silage during the aerobic exposure stage. Moon (1983) reported that VFAs could protect silage against aerobic yeasts and molds. The result of the aerobic stability test showed that P and PL silages were better for aerobic stability as indicated by longest aerobic stable hours, higher LA content, lower $\mathrm{pH}$ and yeasts numbers than other silages.

\section{Conclusions}

According to the results of our study, it was concluded that adding LAB increased the LA and CP content during ensiling, and had no effect on the aerobic stability of oats-common vetch mixed silage. Applying propionic acid decreased LA content during ensiling, and preserved more WSC which stimulated LA production during aerobic exposure stage, thus applying propionic acid significantly improved aerobic stability of oats-common vetch mixed silage. Applying LAB together with propionic acid could not only improve the fermentation quality, but also aerobic stability of oats-common vetch mixed silage on the Tibetan plateau.

\section{ACKNOWLEDGMENTS}

This work was supported by the grant for key techniques research in straw-grass mixed silage from Tibet (XZ20093ZD), National '12th Five-Year' Plan for Science and Technology: Comprehensive treatment key technology and demonstration project of the Degraded grassland in north Tibetan Plateau (2011BAC09B03) and Tibet innovation platform construction by Chinese Academy of Sciences 'construction and demonstration of agriculture and animal husbandry combination technology to promote the income of farmers and herdsmen in Tibet'.

\section{REFERENCES}

Adesogan AT, Salawu MB. 2002. The effect of different additives on the fermentation quality, aerobic stability and in vitro digestibility of pea/wheat bi-crop silages containing contrasting pea to wheat ratios. Grass and Forage Science 57, 25-32.

Adesogan AT, Salawu MB. 2004. Effect of applying formic acid, heterolactic bacteria or homolactic and heterolactic bacteria on the fermentation of bi-crops of peas and wheat. Journal of the Science of Food and Agriculture 84, 983-992.

Assefa G, Ledin I. 2001. Effect of variety, soil type and fertiliser on the establishment, growth, forage yield, quality and voluntary intake by cattle of oats and vetches cultivated in pure stands and mixtures. Animal Feed Science and Technology 92, 95-111.

Barker SB, Summerson WH. 1941. The colorimetric determination of lactic acid in biological material. Journal of Biological Chemistry 138, 535-554.

Basso FC, Bernardes TF, Roth APDTP, Lodo BN, Berchielli TT, Reis RA. 2012. Fermentation and aerobic stability of corn silage inoculated with Lactobacillus buchneri. Revista Brasileira de Zootecnia 41, 1789-1794.

Baytok E, Aksu T, Karsli MA, Muruz H. 2005. The effects of formic acid, molasses and inoculant as silage additives on corn silage composition and ruminal fermentation in sheep. Turkish Journal of Veterinary and Animal Science 29, 469-474.

Bilal MQ. 2009. Effect of molasses and corn as silage additives on the characteristics of mott dwarf elephant grass silage at different fermentation periods. Parameters 45, 19-23.

Britt DG, Huber JT, Rogers AL. 1977. Fungal growth and acid production during fermentation and refermentation of organic acid treated corn silages. Journal of Dairy Science 58, 532-539.

Broderick GA, Kang JH. 1980. Automated simultaneous determination of ammonia and total amino acids in ruminal fluid and in vitro media. Journal of Dairy Science 63, 64-75.

Cao J, Holden NM, Lü XT, Du G. 2011. The effect of grazing management on plant species richness on the QinghaiTibetan Plateau. Grass and Forage Science 66, 333-336.

Fraser MD, Fychan R, Jones R. 2000. Voluntary intake, digestibility and nitrogen utilization by sheep fed ensiled forage legumes. Grass and Forage Science 55, 271-279.

Garcia AD, Olson WG, Otterby DE, Linn JG, Hansen WP. 1989. Effects of temperature, moisture, and aeration on fermentation of alfalfa silage. Journal of Dairy Science $\mathbf{7 2}$, 93-103.

Horii S, Kurata Y, Hayashi Y, Tanabe S. 1971. Physicochemical analytical method for nutritional experiments. In: Morimoto $\mathrm{H}$ (ed.), Animal Nutrition Testing Method, 1st edn. pp. 280-298. Yokendo, Tokyo. (In Japanese)

Huber JT, Soejono M. 1977. Organic acid treatment of high dry matter corn silage fed to lactating dairy cows. Journal of Dairy Science 59, 2063-2070.

Huisden CM, Adesogan AT, Kim SC, Ososanya T. 2009. Effect of applying molasses or inoculants containing homofermentative or heterofermentative bacteria at two rates 
on the fermentation and aerobic stability of corn silage. Journal of Dairy Science 92, 690-697.

Kaiser AG, Curll ML. 1987. Improving the efficiency of forage conservation from pastures. In: Wheeler JL, Pearson CJ, Robards GE (eds), Temperate Pastures: Their Production, Use and Management, pp. 397-411. CSIRO Publishing, Melbourne.

Kennelly JJ, Weinberg ZG. 2003. Small grain silage. In: Buxton DR, Muck RE, Harrison JH (eds), Silage Science and Technology, pp. 749-779. ASA-CSSA-SSSA, Madison, WI.

Krishnamoorthy U, Muscato TV, Sniffen CJ, Van Soest PJ. 1982. Nitrogen fractions in selected feedstuffs. Journal of Dairy Science 65, 217-225.

Lauriault LM, Kirksey RE. 2004. Yield and nutritive value of irrigated winter cereal forage grass-legume intercrops in the Southern High Plains, USA. Agronomy Journal 96, 352-358.

Lunnan T. 1989. Barley-pea mixtures for whole crop forage. Effects of different cultural practices on yield and quality. Norwegian Journal of Agricultural Sciences 3, 57-71.

Mandebvu P, West JW, Froetschel MA, Hatfield RD, Gates RN, Hill GM. 1999. Effect of enzyme or microbial treatment of bermudagrass forages before ensiling on cell wall composition, end products of silage fermentation and in situ digestion kinetics. Animal Feed Science and Technology 77, 317-329.

McDonald P, Edwards RA, Greenhalgh JFD, Morgan CA. 2002. Animal Nutrition, 6th edn. Longman Scientific and Technical, Harlow.

McDonald P, Henderson AR, Heron SJE. 1991. Microorganisms. In: McDonald P, Henderson AR, Heron SJE (eds), The Biochemistry of Silage, pp. 81-151. Chalombe Publications, Marlow.

Moon NJ. 1983. Inhibition of the growth of acid tolerant yeasts by acetate, lactate and propionate and their synergistic mixtures. Journal of Applied Microbiology 55, 453460.

Muck RE, Kung Jr L. 1997. Effects of silage additives on ensiling. In: Muck RE, Kung Jr L (eds), Proceedings of the Silage: Field to Feed Bunk, pp. 187-199. NRAES-99. Northeast Regional Agricultural Engineering Service, Ithaca, NY.

Playne MJ, McDonald P. 1966. The buffering constituents of herbage and silage. Journal of Science Food and Agriculture 17, 264-266.

Pursiainen P, Tuori M. 2008. Effect of ensiling field bean, field pea and common vetch in different proportions with whole-crop wheat using formic acid or an inoculant on fermentation characteristics. Grass and Forage Science 63, $60-78$.
Ranjit NK, Kung JL. 2000. The effect of lactobacillus buchneri, lactobacillus plantarum, or a chemical preservative on the fermentation and aerobic stability of corn silage. Journal of Dairy Science 83, 526-535.

Shao T, Shimojo M, Wang T, Masuda Y. 2005. Effect of additives on the fermentation quality and residual monoand di-saccharides compositions of Forage Oats (Avena sativa L.) and Italian Ryegrass (Lolium multiflorum Lam.) silages. Asian Australasian Journal of Animal Sciences 18, 1582-1588.

Takahashi T, Horiguchi K, Goto M. 2005. Effect of crushing unhulled rice and the addition of fermented juice of epiphytic lactic acid bacteria on the fermentation quality of whole crop rice silage, and its digestibility and rumen fermentation status in sheep. Animal Science Journal 76, 353-358.

Thomas TA. 1977. An automated procedure for the determination of soluble carbohydrates in herbage. Journal of Science of the Food and Agriculture 28, 639-642.

Titterton M, Maasdorp BV. 1997. Nutritional improvement of maize silage for dairying: mixed crop silages from sole and intercropped legumes and a long season variety of maize. 2. Ensilage. Animal Feed Science and Technology 69, 263-270.

Van Soest PJ, Robertson JB, Lewis BA. 1991. Methods for dietary fiber, neutral detergent fiber, and non-starch polysaccharides in relation to animal nutrition. Journal of Dairy Science 74, 3583-3597.

Weinberg ZG. 2008. Preservation of forage crops by solidstate lactic acid fermentation-ensiling. In: Weinberg ZG (ed.), Current Developments in Solid-State Fermentation, pp. 443-467. Springer, New York.

Weinberg ZG, Ashbell G, Azrieli A, Brukental I. 1993. Ensiling peas, ryegrass and wheat with additives of lactic acid bacteria (LAB) and cell wall degrading enzymes. Grass and Forage Science 48, 70-78.

Weissbach F, Honig H. 1996. On the anticipation and control of the run of fermentation in solage making from extensively grown forages. Landbauforschung $V$ lkenrode 46, 10-17.

Wilkinson JM. 2005. Silage. Chapter 19 In: Wilkinson JM (ed.), Analysis and Clinical Assessment of Silage, pp. 198-208. Chalcombe Publications, Marlow.

Woolford MK. 1975. Microbiological screening of straight chain fatty acids $\left(\mathrm{C}_{1}-\mathrm{C}_{12}\right)$ as potential silage additives. Journal of Science of the Food and Agriculture 26, 219-228.

Woolford MK. 1984. Managing aerobic deterioration in silage. In: McCullough ME, Bolsen KK (eds), Silage Management, pp. 42-75. National Feed Ingredients Association, Silage Technology Division, West Des Moines, IA. 